\title{
O SUPORTE DE GÊNEROS FACEBOOK
}

\author{
FACEBOOK, MEDIUM OF GENRES
}

\author{
Maria Margarete Fernandes de Sousa ${ }^{1}$ \\ Francisco de Freitas Leite ${ }^{2}$ \\ Patrícia Gomes de Mello ${ }^{3}$ \\ Thamyres Barrozo de Paula ${ }^{4}$ \\ Rosângela Soares Lima ${ }^{5}$
}

\begin{abstract}
Resumo: Este trabalho objetiva analisar o Facebook como um suporte de gêneros, para o que utiliza páginas de empresas que divulgam seus produtos. Como aporte teórico para a discussão de gênero e suporte, pauta-se em Bakhtin (2003), Marcuschi (2008), Bhatia (1993; 2004), Swales (1990; 2009), entre outros. Para o anúncio publicitário, toma como aporte teórico Gonzales (2003) e Carvalho (2014). Para análise do objeto, seleciona duas páginas de Facebook de duas marcas brasileiras, Havaianas e Natura. Os resultados mostram que o Facebook comporta-se como autêntico suporte de gêneros, capaz de veicular e modificar os gêneros que nele se inserem. Palavras-chave: Gêneros discursivos; anúncio publicitário; novas tecnologias.
\end{abstract}

\begin{abstract}
This article intends to analyze Facebook as a medium of genres, which is done through advertisement pages of companies and their products. The theoretical contribution to the discussion of genre and medium is based on Bakhtin (2003), Marcuschi (2008), Bhatia (1993; 2004), Swales (1990; 2009), among others. Regarding the advertisement discourse, we refer to the theoretical contributions of Gonzales (2003) and Carvalho (2014). For the analysis of our objects, we select two Facebook pages of two Brazilian brands, Havaianas and Natura. The results show that Facebook behaves as an authentic medium of genres, able to spread and modify the genres that are inserted in it.
\end{abstract}

Keywords: Discursive genres; advertisement; new technologies.

\footnotetext{
${ }^{1}$ Doutora em Linguística. Professora do Curso de Letras e do Programa de Pós-Graduação em Linguística da Universidade Federal do Ceará - UFC. Coordenadora do Grupo de Pesquisa Gêneros: estudos teóricos e metodológicos/GETEME. E-mail: margarete.ufc@gmail.com

${ }^{2}$ Doutor em linguística. Professor do Curso de Letras e do Programa de Pós-Graduação em Letras da Universidade Regional do Cariri - URCA. E-mail: freitas_leite@ hotmail.com

${ }^{3}$ Mestra e Doutoranda no Programa de Pós-graduação em Linguística - Proling, da Universidade Federal da Paraíba - UFPB. E-mail: pathy.gomes13@gmail.com

${ }^{4}$ Mestra em Linguística pela Vrije Universiteit Brussel - VUB, na Bélgica. E-mail: thamyresbarrozo@ gmail.com

${ }^{5}$ Graduada em Letras e mestranda no Programa de Pós-graduação em Letras, da Universidade Federal do Ceará UFC. E-mail: rosangelasoaresdelima@gmail.com
} 


\section{Introdução}

O século XXI é marcado pelas relações sociais intermediadas pela tecnologia, que se tornou fator de mudança em todos os setores da sociedade, seja na família, na escola, seja nas atividades cotidianas como, por exemplo, comprar roupas, alimentos, ingressos para cinema, pratos promocionais nos restaurantes, pacotes em salões de beleza, entre outras, o que favoreceu o surgimento de novos gêneros, bem como novas formas de divulgação e de postagens desses gêneros.

Em razão dessa realidade, os estudos relacionados aos gêneros e às novas tecnologias, que são recentes e remontam a meados do século $\mathrm{XX}$, ganharam impulso, novas perspectivas e renovados interesses investigativos. Assim, não podemos deixar de mencionar a importância dos estudos com os gêneros que circulam na Internet, como lembra Lima-Neto (2014).

No Brasil, Marcuschi e Xavier (2005) foram pioneiros na abordagem sobre o hipertexto, tema que está diretamente ligado ao universo de interesse dos gêneros que circulam nesse eixo comunicativo e que cumprem a função social de divulgar produtos e serviços do interesse de um público específico. Segundo os autores, "todas as tecnologias comunicacionais novas geram ambientes e meios novos" (MARCUSCHI; XAVIER, 2005, p. 26), como aconteceu com o Facebook, que, entre outras funções, atua como suporte de gêneros, como vamos demonstrar.

Assim, defendemos que as mudanças sociais e o advento das tecnologias são fatores de mudanças sociais que, em certa medida, influenciaram e motivaram esta pesquisa. Diante disso, analisar páginas de Facebook como suporte dos anúncios ali postados torna-se relevante devido à grande quantidade de pessoas que fazem uso desse gênero discursivo, cuja finalidade é a divulgação e venda de bens (produtos e serviços).

Neste artigo, demonstraremos o Facebook como suporte de gênero que pode modificá-lo ao hospedá-lo. Para isso, discutiremos as concepções de gênero, considerando Bakhtin (2003), Marcuschi (2008), Bhatia (1993; 2004), Swales (1990; 2009), entre outros; e de suporte de gênero com base em Marcuschi (2008), Távora (2008) e Lima-Neto (2014). Além disso, apresentaremos peculiaridades do uso da linguagem e de formas de interação nesse espaço virtual.

Passemos às discussões, em seguida, faremos uma breve descrição da metodologia adotada nesta pesquisa. 


\section{Concepções de gênero}

Com o advento da Internet, inúmeros gêneros discursivos têm surgido e despertado o interesse de pesquisadores da área da Linguística, como já sinalizamos na introdução deste artigo. O surgimento da Internet possibilitou o surgimento do Facebook, uma rede social, que tem servido, principalmente, como forma de interação entre indivíduos e entre empresas e indivíduos, como no caso das páginas de Facebook das marcas Havaianas e Natura das quais coletamos os anúncios que serão analisados neste artigo.

Bakhtin (2003), filósofo da linguagem, em seus estudos sobre gênero, afirma que a língua é empregada nas atividades humanas por meio de enunciados e que cada enunciado é singular, pois parte de escolhas individuais dos falantes, "mas cada campo de utilização da língua elabora seus tipos relativamente estáveis de enunciado, os quais denominamos gêneros do discurso" (BAKHTIN, 2003, p. 262, grifo do autor). Essa concepção baseia-se na realidade e no comportamento das ações comunicativas dos indivíduos.

No viés da tradição sociorretórica de estudo dos gêneros, Miller (2012, p. 23) definiu gêneros "como ações retóricas tipificadas baseadas em situações recorrentes", ou seja, os gêneros, em geral, caracterizam-se por serem ações comunicativas que se valem de uma estrutura recorrente que é compartilhada e aceita por um determinado grupo social. No entanto, essa definição não dá conta das características dos gêneros, principalmente no que se refere às suas funções sociais. Swales (1990, apud BAWARSHI; REIFF, 2013, p. 65) afirma que os gêneros são "ações linguísticas e retóricas que envolvem o uso da linguagem para comunicar algo a alguém, em algum momento, em algum contexto e para algum propósito", o que também não atende satisfatoriamente ao todo que caracteriza o fenômeno, pois os gêneros exercem funções sociais em razão das culturas nas quais se inserem.

Como podemos constatar, essas concepções, embora abordem o gênero como práticas sociais comunicativas, que se caracterizam por apresentarem propósitos comunicativos específicos $^{6}$ e destinatários específicos, ainda carecem de complementações. Além da questão

\footnotetext{
${ }^{6}$ Tomamos por propósito comunicativo específico a capacidade que os gêneros apresentam em propor "coisas" específicas mais direcionadas ao seu leitor. No caso da publicidade, o gênero anúncio publicitário apresenta como propósito comunicativo geral anunciar, convencer e vender o bem ofertado (BHATIA, 1993). Os específicos estão
} 
cultural que deve ser contemplada, ainda lhes faltam as características dos gêneros em função do meio virtual.

Segundo Biasi-Rodrigues, Hemais e Araújo, a primeira característica para se identificar um gênero está relacionada à ideia de classe. Confiramos com suas palavras: "O gênero é identificado como uma classe de eventos comunicativos realizados por meio da linguagem verbal, e esses eventos são constituídos de discurso, participantes, funções do discurso e ambiente onde se produz e recebe o discurso" (BIASI-RODRIGUES; HEMAIS; ARAÚJO, 2009, p. 21).

Essa primeira característica que podemos atribuir ao gênero, apontada pelos autores, reforça as demais no que concerne à sua identificação, por situar o gênero como uma classe de eventos comunicativos.

A segunda característica apresentada por Swales para a identificação do gênero é o propósito comunicativo. Para o autor, o propósito comunicativo é traço básico para a identificação dos gêneros. Questões problemáticas, no entanto, circundam o propósito comunicativo, pois, não raro, um mesmo gênero apresenta mais de um propósito comunicativo, o que o próprio autor denomina de repropósito ${ }^{7}$. Como advertem Biasi-Rodrigues, Hemais e Araújo (2009), os membros das comunidades discursivas podem produzir texto que compõem um gênero, os quais possuem propósitos comunicativos definidos, próprios para expressar sua intenção comunicativa. Um jornalista, por exemplo, pode utilizar-se do gênero notícia para comunicar um determinado fato, próprio do gênero em questão; porém, além das informações relativas à notícia, pode-se inferir seu posicionamento político-ideológico, o que leva o leitor a captar na intencionalidade do autor outro propósito para o gênero; por isso o propósito comunicativo, embora fundamental na produção dos gêneros, deve ser considerado com certa cautela.

Swales, então, apresenta a seguinte definição de gênero:

Um gênero compreende uma classe de eventos comunicativos, cujos exemplares compartilham os mesmos propósitos comunicativos. [...] Além do propósito, os exemplares do gênero demonstram padrões semelhantes, mas com variações em termos de estrutura, estilo, conteúdo e público-alvo. Se forem realizadas todas as expectativas em relação àquilo que é altamente provável para o gênero, o exemplar será visto pela comunidade discursiva original como um protótipo [ou seja, o exemplo mais típico de determinado gênero]. Os gêneros têm nomes que são herdados e produzidos pelas

relacionados às formas como esse propósito será atendido. Os anúncios seduzem, incitam, provocam etc. para fazer o seu leitor, possível consumidor e adquirir o bem anunciado.

${ }^{7}$ A discussão sobre esse desdobramento não cabe aqui, pois não será objeto de análise. 
comunidades discursivas e importados por outras comunidades. (SWALES, 1990, p. 58, apud BIASI-RODRIGUES; HEMAIS; ARAÚJO, 2009, p. 22-23).

Em sua definição de gênero, Swales aponta traços importantes que caracterizam e particularizam os gêneros, como: a) a estrutura esquemática do discurso, que interpretamos como ação retórica do gênero; b) estilo, que entendemos como elementos linguísticos inerentes ao gênero (e ao autor), que lhe confere identidade; c) conteúdo (cada gênero trata, em certa medida, de conteúdo, assunto próprio); d) público-alvo; o interlocutor é o ponto de partida e de chegada na produção do gênero.

Diante disso, podemos afirmar que os gêneros são fruto de ações tipificadas dentro das comunidades discursivas e, por isso, mudanças sociais acarretam mudanças genéricas que moldam os gêneros e são moldadas por eles. Essa perspectiva atende, particularmente, ao nosso objetivo de pesquisa, pois partiremos dessa perspectiva de mudança que interfere no gênero publicitário anúncio no meio midiático, mais especificamente no (suporte) Facebook, que contribui para as mudanças genéricas em função das mudanças sociais; logo, atendem às expectativas dos destinatários, que chamamos de coenunciadores.

\subsection{Gêneros publicitários}

O que entendemos por publicidade extrapola o âmbito puramente comercial. As publicidades vendem muito mais que produtos e serviços; vendem sonhos, desejos, poder etc.

Concordamos com Martins (1997, p. 122), para quem “a função do anúncio é cumprida, é eficaz, quando ele consegue transformar o produto em objeto de prazer, apresentando-o como solução para os problemas do leitor, ou seja, quando cria a necessidade de compra". Essa ideia é reforçada em Carvalho (2014), quando a autora menciona que, na publicidade, o anúncio transforma o produto em objeto de desejo; é, por isso, a linguagem da sedução.

Compreendemos que esta concepção pode atingir os anúncios no meio virtual também. Entendemos, contudo, que, nas páginas do Facebook (meio virtual), o uso da linguagem, aliado a outras formas de interação, processam-se de maneira diferenciada, exatamente em função das especificidades do meio virtual: recursos hipertextuais, formas diretas e reais de interação, possibilidade de retorno imediato às necessidades comunicativas dos usuários etc. Isso, a nosso 
ver, confere ao anúncio ali postado seu status genérico, pois o torna capaz de cumprir as funções sociais para as quais é produzido naquele meio.

Como todo gênero discursivo, também o anúncio publicitário apresenta uma estrutura organizacional, tanto do ponto de vista da forma quanto do discurso; ações retóricas discursivas, ou seja, marcas linguísticas próprias do gênero: uso de verbos no imperativo, função conativa de linguagem, organização textual predominantemente injuntiva (MOREIRA, 2009). Além disso, como lembra Gonzales (2003), podemos aliar às características discursivas, a estrutura do anúncio, que, em geral, compõe-se de título, subtítulo, corpo do texto, slogan, assinatura e marca, elementos que flagramos, também, nos anúncios das páginas do Facebook; por isso faz-se necessário que não percamos de vista os aspectos funcionais nem os estruturais do anúncio.

$\mathrm{O}$ anúncio publicitário, em geral, contém elementos não verbais, imagens que podem "ter significado denotativo ou conotativo. Seu sentido polissêmico é delimitado pelo título do anúncio, mensagem linguística que acompanha e orienta sua significação" (GONZALES, 2003, p. 19). Concordamos com Gonzales e reforçamos que, hoje, é imperioso ao anúncio o uso da linguagem não verbal, também, que transcende a imagem. O anunciante e/ou publicitário usam, além da imagem, vários outros recursos imagéticos, como cores variadas, formas, fontes diferentes, que garantem clareza, leveza e mais informatividade ao texto do anúncio; com isso, a possibilidade de persuadir o leitor fica cada vez mais assegurada.

$\mathrm{O}$ texto não verbal e o texto verbal precisam estar alinhados, formando uma coerência que produzirá os efeitos pré-estabelecidos pelo anunciante no receptor. Para isso, o texto verbal se utiliza de argumentos que devem estimular o leitor a consumir determinado produto ou serviço, tais como o uso de uma proposição como verdade, descrição das qualidades e utilidades do produto, descrição da superioridade do produto, causas e consequências de adquirir e não adquirir o produto e argumentos emotivos visando alcançar os sentimentos do receptor (MARTINS, 1997).

Nos anúncios que circulam nas páginas do Facebook, foi possível perceber certas mudanças em relação à forma de utilização do texto verbal, que revelam nuanças desse gênero, tema sobre o qual falaremos adiante. Passemos à discussão sobre suporte de gêneros e sobre Facebook, foco central neste estudo. 


\section{Concepções de suporte de gêneros}

A noção de suporte tem sido fonte de debates e discussões nos estudos linguísticos e está longe de ser consensual. Para essa discussão, tomamos como base os estudos de Marcuschi (2008) e de Távora (2008).

Marcuschi (2008, p. 174), que consideramos pioneiro nessa discussão, entende suporte de um gênero como um "locus físico ou virtual com formato específico que serve de base ou ambiente de fixação do gênero materializado como texto". O suporte, para ele, fixa o gênero a fim de que este cumpra seus propósitos comunicativos.

Essa definição foi ampliada e modificada por Távora (2008, p. 23), que entende que:

Um suporte é uma entidade capaz de estabelecer interação; para tanto, ele pode se realizar materialmente, o que implica uma arquitetura formal. Forma não necessariamente é o arranjo da matéria que constitui o suporte, como no caso da celulose, que encadernada forma o livro; mas também se refere ao modo de existência que a linguagem assume devido ao material tecnológico responsável por sua difusão, registro ou arquivamento.

A partir dessa definição, o suporte não mais é definido apenas como um locus material de fixação do gênero que suporta textos, mas como entidade que permite a interação, ou seja, que permite maior contato e aproximação entre os interlocutores. Com isso, entendemos que o suporte limita, molda e que, por isso, é responsável por modificação no gênero. O suporte, nessa perspectiva, possibilita que o gênero circule na sociedade e que cumpra a função social de veicular as informações e promover a interação entre os usuários nas diversas e diferentes ações sociais exigidas pela sociedade em que eles existem. Tomemos como exemplo um jornal impresso e um jornal virtual que podem conter a mesma informação; no entanto, as formas de recepção do gênero não ocorrem igualmente nos dois formatos. O jornal impresso apresenta as informações em linguagem escrita (verbal e/ou visual). Um jornal virtual, sendo um hipertexto, embora apresente a mesma linguagem, contém links e hiperlinks que possibilitarão aos leitores novas maneiras de acesso à informação, como o acesso a textos complementares, uso de vídeos etc., que entendemos como partes do enunciado, embora preservem suas identidades (TÁVORA, 2008). São essas diferentes formas interativas que, julgamos, afetam o modo como os gêneros são atualizados nos suportes, ponto de vista importante para o que defendemos com respeito ao Facebook. 
Diante dessas concepções, defendemos que o gênero discursivo é influenciado pelo suporte, condição que amplia ou limita as ações do enunciado. Cada suporte tem uma maneira específica de apresentar um enunciado, como exemplificamos com o jornal impresso e virtual. Uma notícia em um jornal impresso apresenta uma determinada configuração. Ela deve ser sucinta e geralmente apresenta imagens relacionadas ao que está escrito. Da mesma forma, acontece com o gênero anúncio em jornal impresso. $\mathrm{O}$ anúncio é estático e pode conter elementos verbo-visuais. Se tomarmos, no entanto, esses dois gêneros e os transpormos para outros suportes, perceberemos que estes sofrem alterações; por exemplo, a notícia reportada em um jornal online pode apresentar vídeos e um layout que possibilitarão que o leitor encontre mais informações sobre aquela notícia através de links na página da web. O gênero anúncio publicitário também sofre modificações ao ser transposto para outro suporte. Tomemos como exemplo o outdoor. Um anúncio em um outdoor, além de tamanho aumentado, precisa apresentar mais informações visuais e menos elementos verbais, para que fique mais objetivo, afinal o propósito comunicativo desse gênero, nesse suporte, é anunciar um produto ou serviço de forma que o leitor pare, no semáforo, por exemplo, e tenha acesso a ele de forma rápida e eficaz.

Para reforçar essa concepção, confiramos esta passagem de Lopes (2008) que cita Marchuschi (2003) e ratifica a ideia de que um gênero tende a mudar dependendo do suporte que o difunde:

\begin{abstract}
Marcuschi (2003) aponta a questão da reversibilidade de funções, como um dos aspectos influenciados pelos suportes. Por exemplo, cita a transferência dos seguintes gêneros uma carta pessoal, uma carteira de identidade e um anúncio publicitário - de seu habitat convencional para um livro didático. Julgamos haver, nessa transferência, repropósitos comunicativos nesses gêneros, que os tornam diferentes de sua situação inicial em seus meios "naturais" de circulação. (LOPES, 2008, p. 64).
\end{abstract}

Isso comprova, como já colocado, que o suporte não é apenas um locus material e virtual de veiculação do gênero, como defende Marcuschi (2008), mas também um constituinte (parte do gênero) que provoca alterações nos gêneros de acordo com suas características e com os objetivos da sociedade. Essas concepções reforçam nosso ponto de vista de que o Facebook é um suporte de gêneros, já que é capaz de provocar alterações significativas no gênero, o que demonstraremos no item a seguir. 


\subsection{Facebook: linguagem e interação}

O Facebook foi lançado em 2004, nos Estados Unidos, por Mark Zuckerberg, um exestudante de Harvard. Segundo o seu próprio site, sua missão é dar às pessoas o poder de dividir e de tornar o mundo mais aberto e conectado. Araujo et al (2009, p. 5) comentam:

\footnotetext{
O site é gratuito para usuários, os quais podem se juntar em uma ou mais redes, como a de um colégio ou de uma banda. Nele os usuários criam perfis que contêm fotos e listas de interesses pessoais, trocando mensagens privadas e públicas entre si e participantes de grupos de amigos. A visualização de dados detalhados dos membros é restrita para membros de uma mesma rede ou amigos confirmados.
}

O Facebook, apesar de ser um espaço virtual para interações sociais, em que os usuários utilizam a linguagem verbal e não verbal, torna-se um suporte no momento em que abriga e veicula diferentes gêneros discursivos. Além disso, o Facebook atende a essa condição, pois configura-se como um ambiente interativo, que permite aos usuários transitar por links que garantem a eficácia das hipertextualidades, necessárias à complementação das informações. Essa característica do Facebook atende ao que defende Bernardo (2014, p. 4):

Diante da versatilidade textual do Facebook e de seu caráter fomentador de mudanças na comunicação e expressão, percebe-se que realmente essa plataforma possibilita, por meio de seu material textual, um ambiente de recriação e redescobertas de gêneros textuais, o que vem ao encontro da transmutação de gêneros evidenciada por Bakhtin.

Ao defender que o Facebook possibilita, por meio de seu material textual, um ambiente de recriação e redescobertas de gêneros textuais, o autor corrobora nosso posicionamento de que o Facebook é um autêntico suporte de gêneros discursivos. O suporte Facebook torna-se uma alternativa viável para empresas que buscam proximidade e agilidade na comunicação com os clientes; por isso a publicidade de serviços e produtos, como a que analisamos mais adiante, tem encontrado no Facebook um meio de se comunicar com os clientes, sondar os gostos do momento, possibilitando-lhes, assim, avaliar o que é viável ou não, conforme suas necessidades ou anseios.

Esses aspectos são importantes termômetros para a confirmação da nossa hipótese de que o Facebook, por sugerir e até exigir modificações textuais, é um suporte de gêneros, o que demonstraremos, na análise, a partir dos anúncios das Havaianas e da Natura. 


\section{Metodologia}

Para este estudo, selecionamos duas páginas de Facebook de duas marcas brasileiras, Havaianas e Natura, para o que consideramos o número de curtidas, no caso, mais de 5.000.000 na página, das quais coletamos 10 anúncios: 5 das Havaianas e 5 da Natura. Em seguida, selecionamos dois anúncios, um de cada página, para representar, de forma ilustrativa, os resultados encontrados nos 10 anúncios analisados.

Fizemos print screens das postagens dos anúncios de cada página; depois dividimos os print screens em imagens e texto verbal, inclusive os comentários. Os anúncios (imagens) foram analisados, primeiramente, considerando aspectos verbo-visuais, incluindo os comentários para cada anúncio, os quais consideramos parte dos textos dos anúncios.

Procedemos à análise sob o caráter teórico das páginas publicitárias de Facebook com respaldo nas teorias e teóricos já mencionados e comentados. O apoio teórico nos autoriza ao entendimento de que os anúncios postados nas páginas do Facebook caracterizam-se como gêneros discursivos, que compõem a colônia ${ }^{8}$ de gêneros anúncios publicitários.

Assim como os demais gêneros, também os anúncios que circulam nas páginas do Facebook compõem essa colônia de gêneros anúncios, como preconizado por Bhatia (1993) e referendada por Lopes (2008).

Com uma abordagem qualitativa, de caráter indutivo, analisamos os 10 anúncios, 5 da marca Havaianas e 5 da Natura, os quais são representados, na seção de análise, por 1 anúncio de cada marca.

\section{0 suporte Facebook e os anúncios publicitários das Havaianas e da Natura}

Esta seção está dividida em três partes; a primeira delas traz uma introdução à maneira como compreendemos o Facebook, isto é, como um autêntico suporte de gêneros que favorece mudanças nos gêneros, tais como no anúncio publicitário; a segunda parte traz a análise de um

\footnotetext{
${ }^{8}$ Para Bhatia (1993, 1999), uma colônia ou constelação de gêneros promocionais caracteriza-se por uma variedade de gêneros relacionados, tais como: anúncios promocionais de venda, carta de solicitação de emprego, sinopse de livro, anúncios de computadores, anúncios de cosméticos etc., que compartilham o mesmo propósito comunicativo. (SOUSA, 2005, p. 42). Ainda a respeito das colônias de gêneros anúncios, Lopes (2008, p.145-146) comenta: "Não temos a pretensão de dar uma definição fechada para esses gêneros, entendemos, apenas, que cada um deles atende a necessidades sociais específicas, por isso consideramos que são distintos, apesar de compartilharem características que os aproximam, não há uma fronteira sólida entre eles, mas uma fluidez, a qual permite reconhecer esses gêneros que podem pertencer a uma colônia de gêneros anúncios".
} 
post da página das Havaianas e de um outro da página da Natura no Facebook, com foco na interação entre emissor/anunciante e receptor/consumidor na realização dos objetivos dos gêneros publicitários; a terceira parte traz um resumo das marcas textual-discursivas nos textos publicitários analisados da Natura e das Havaianas no Facebook.

\subsection{Considerações preliminares}

O Facebook possui uma configuração que permite criar páginas diversas, entre elas as páginas para fins publicitários. Nesse suporte, os anúncios, além de apresentarem-se em uma coluna à direita, também são divulgados como posts/postagens ${ }^{9}$ no mural/feed ${ }^{10}$ de notícias e podem receber curtidas, compartilhamentos e comentários.

A análise realizada, a partir de 10 (dez) anúncios publicitários (5 das Havaianas e 5 da Natura), permitiu-nos constatar que o Facebook é um autêntico suporte de gêneros e que promove modificações nos gêneros, no caso em discussão, no anúncio publicitário ${ }^{11}$, o que nos autoriza a afirmar que este é um (novo) gênero da colônia de gêneros anúncios publicitários.

Para exemplificar e comprovar nossas constatações, analisamos um post de cada página, Havaianas e Natura, que ilustram e resumem o que afirmamos. Além disso, apresentamos um quadro (no tópico de análise) que resume o resultado dos 10 anúncios analisados.

\subsection{Análise dos anúncios}

Havaianas é uma marca brasileira de sandálias fundada em 1962. A marca e seus produtos estão presentes em mais de 80 países. A página das Havaianas no Facebook possui, até o momento da pesquisa, 6.320 .786 curtidas. A missão da marca, como ela própria divulga, é difundir a cultura brasileira. Em termos gerais, em sua página no Facebook, a empresa Havaianas afirma que os brasileiros têm os pés mais alegres e famosos do mundo e que "quando um pé entra nas havaianas, está entrando em território brasileiro" (HAVAIANAS, 2016, não paginado).

A Natura é uma marca de produtos de beleza fundada em 1969. A página da Natura no Facebook tem, também até o momento desta pesquisa, 10.909.533 curtidas. Em sua página do

\footnotetext{
${ }^{9}$ Publicações de textos verbais ou verbo-visuais no Facebook.

${ }^{10}$ Espaço em que são publicadas as postagens.

${ }^{11}$ Defendemos, com base em Bhatia (1993), a existência de colônia de gêneros publicitários, tema que já foi objeto de estudos realizados por Sousa (2005) e Lopes (2008), entre outros.
} 
Facebook, a Natura se descreve como "uma marca que valoriza a harmonia das pessoas com sua própria beleza. Que inspira o equilíbrio com a natureza." [A missão da empresa] "É criar e comercializar produtos e serviços que promovam o Bem-Estar/Estar Bem" (NATURA, 2016, não paginado).

Esses perfis das empresas e seus posts no Facebook nos auxiliaram e nos orientaram para a análise dos textos/postagens e revelaram-se importantes para confirmar o que defendemos: o suporte modifica o gênero publicitário ao hospedá-lo.

$\mathrm{O}$ texto a seguir refere-se à publicação no mural feito pela própria página das Havaianas. O mural é um recurso oferecido pelo suporte Facebook que permite a interação rápida e rompe distâncias entre a empresa e os consumidores, de maneira a que os consumidores conheçam outros consumidores e, assim, possam influenciar e avaliar positivamente (ou negativamente) o produto. Sugestões postadas nos comentários e o uso de ferramentas como os botões curtir, amei, haha, uau, triste e grr possibilitam aos usuários/consumidores demostrarem reações além da mera aprovação com uma curtida.

O Facebook é um suporte que viabiliza à empresa conhecer as preferências dos usuários/consumidores, garantindo ao gênero anúncio publicitário ser objetivo em sua construção textual e visual, traços que atendem às condições da Web, a qual é descrita por Marcuschi e Xavier (2005, p. 126) como:

[...] uma excelente ferramenta para marketing, vendas e publicidade. Porém, isso não se limita apenas à comercialização de produtos, propriamente ditos, mas também aos textos, que podem combinar ilustrações coloridas trechos de vídeos e som, os quais o interlocutor pode selecionar e percorrer com um simples toque no mouse. Em outras palavras, a Internet tem um grande poder mercadológico que pode ser usado, tanto para a realização de vendas de produtos e serviços, quanto para a distribuição de informações, o que não deixa de ser um marketing.

Ao afirmar que este é um ambiente fértil para a publicidade, ousamos estender as condições a que os autores aludem às redes sociais, no caso, ao Facebook. O texto de anúncio publicitário a seguir, retirado da página das Havaianas, confirma essas e outras condições e características. 

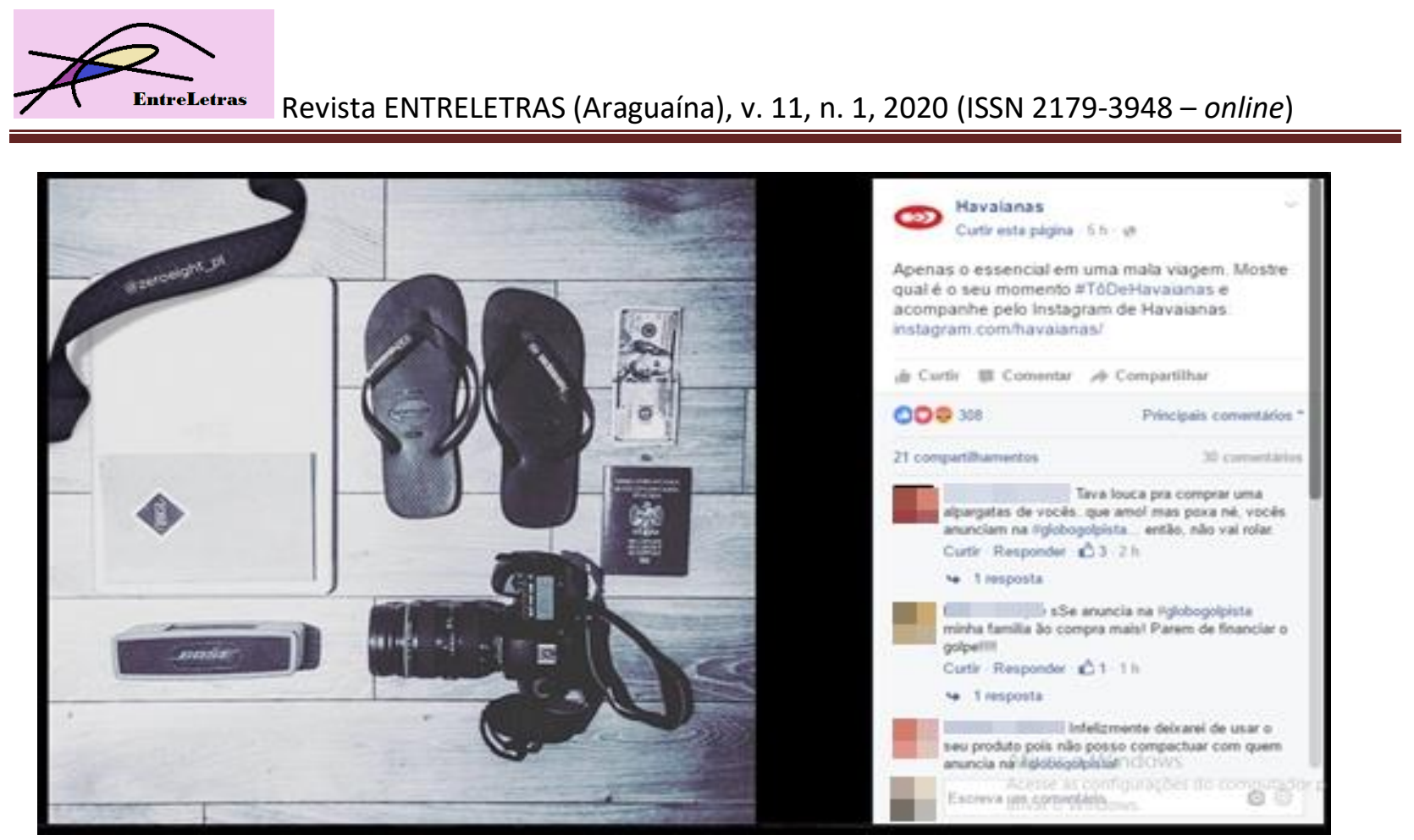

Figura 01 - Texto publicitário das Havaianas. Fonte: Havaianas (2016, não paginado).

O texto publicitário das Havaianas (Figura 01), ora apresentado, constrói-se em grande parte de forma imagética. No entanto, a parte verbal que figura à direita nos parece o diferencial nesse anúncio, pois o texto completa-se pela linguagem verbal: "Apenas o essencial em uma mala (de) viagem. Mostre qual é o seu momento \#TôDeHavaianas e acompanhe pelo Instagram de Havaianas: instagram.com/Havaianas/" (HAVAIANAS, 2016, não paginado), com que a marca tenta convencer o consumidor de que Havaianas é essencial. Além desse texto, há uma mensagem acima, do lado esquerdo na própria imagem (nome da conta do Instagram pertencente à pessoa que fez a fotografia), que colaboram para a construção do texto do anúncio. Essa ação constitui-se importante na constituição desse texto publicitário, pois a empresa utilizou-se de uma fotografia de um provável consumidor para fazer a publicidade de seus produtos. Embora esse seja um recurso já utilizado em anúncios impressos, ele se faz, no meio virtual, de forma mais dinâmica e real, já que registra, de fato, um usuário consumidor do produto. Há também um hyperlink $^{12}$, recurso que permite o acesso ao site da empresa, fazendo com que os usuários consumidores sejam convidados a visitá-lo e a comprar os produtos ali ofertados.

\footnotetext{
${ }^{12}$ Hipertexto/links (elementos hipertextuais) são dispositivos multimodais, tendo em vista que, além de possibilitar a linkagem, se apresentam marcadamente por meio de diferentes recursos semióticos: imagens, ícones, símbolos, cor da fonte, tamanho da fonte etc. Devemos ressaltar que toda essa integração semiótica, recursos multimodais e elementos hipertextuais são combinados e utilizados no meio digital para determinados propósitos comunicativos do gênero textual digital. (BELINI, 2014, grifo do autor). O termo hipertexto foi usado pela primeira vez no início da
} 
$\mathrm{Na}$ imagem do anúncio, pode-se perceber a presença de itens organizados para viagem e nela há um par de Havaianas. Valendo-se dessa imagem, o anunciante tenta tornar o anúncio resultante, inclusive, de ações reais do consumidor: certamente, são itens que o consumidor transporta em suas viagens. Dessa forma, a empresa mostra que ter uma sandália Havaianas é indispensável em uma viagem, por isso a sandália vem ao lado de uma câmera fotográfica, também essencial para registrar momentos inesquecíveis da viagem. Além disso, o consumidor/ cliente deve levar, ainda, o notebook, passaporte e dinheiro, para garantir mais sucesso à viagem.

Além dos traços inerentes à web, tais como o uso de hiperlinks e condições para navegação na página, o Facebook apresenta o traço de interação que, embora seja próprio a todos os gêneros, nesse suporte, acontece de modo diferenciado. O Facebook permite interação imediata e essa interação tem sido aproveitada pelos anunciantes na composição dos textos dos anúncios, como nesses que analisamos. Com isso, entendemos que o suporte Facebook causa alterações nos textos/anúncios devido à relação entre enunciador/vendedor e leitor/consumidor, que se faz diretamente; logo ele interfere na constituição do gênero.

Veremos como isso ocorre observando o recorte que apresentamos do diálogo que está ao lado do texto do anúncio da Figura 01.

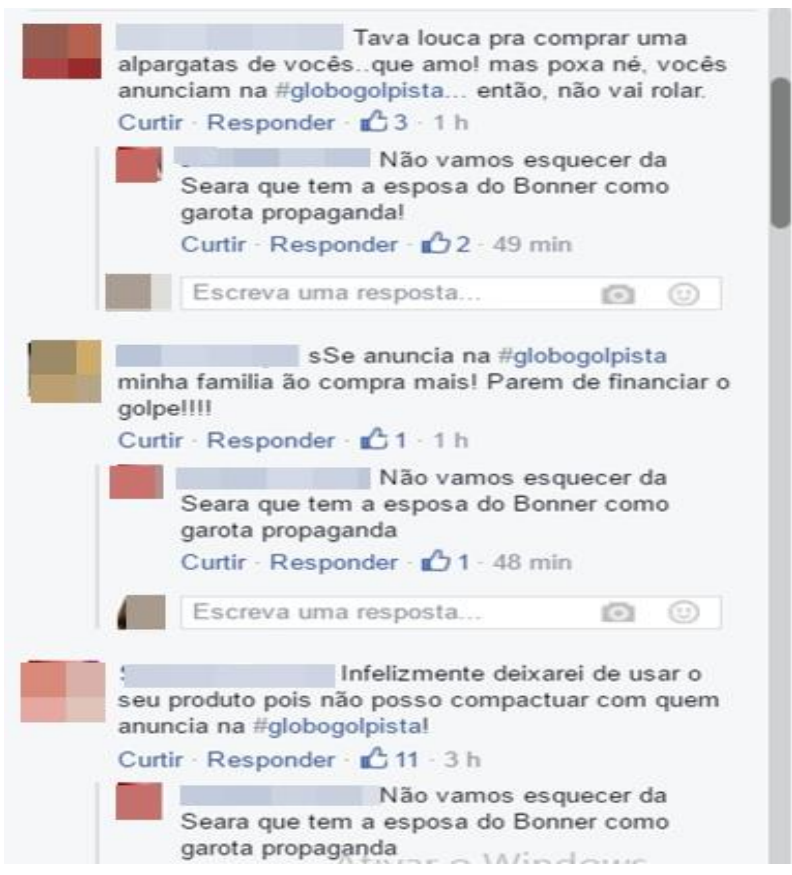

década de 1960, por Theodor H. Nelson, discípulo de Vannevar Bush, em seu trabalho A File Structure for the Complex, the Changingand the Indeterminate, desenvolvido posteriormente em sua obra Literary Machines (1993). Denomina-se hipertexto, então, um modo diferente de ler e escrever desenvolvido pela tecnologia da informação. 
Figura 02 - Comentários sobre o anúncio da Figura 01. Fonte: Havaianas (2016, não paginado).

O Facebook permite, no texto publicitário em questão, uma aparente relação íntima com os usuários que comentam as postagens da Página. Essa possibilidade foi sentida também por Gonzales (2003, p. 14) para quem o "texto publicitário é uma forma de comunicação pública, isto é, que se dirige, em sua grande maioria, ao público anônimo, não conhecido particularmente pelo anunciante". Essa relação de comunicação, todavia, em um só sentido é quebrada pelo Facebook, pois, como vemos no exemplo acima, há um diálogo entre enunciador e consumidor que sugere a quebra do anonimato.

Tais comentários, que podem ser visualizados na figura 2, como Tava louca pra comprar uma alpargatas de vocês ... que amo! Mas poxa né vocês anunciam na \#globogolpista... então não vai rolar, podem influenciar a produção e a construção do texto, pois essa forma de postagem e divulgação tende a considerar e incorporar o que é veiculado na web ${ }^{13}$.

$\mathrm{O}$ enunciador (Havaianas) recebe o feedback dos consumidores em relação à marca. Alguns comentários da Figura 02, inclusive, criticam o anunciante por anunciar seus produtos em uma emissora que patrocina uma determinada vertente política: Infelizmente deixarei de usar o seu produto pois não posso compactuar com quem anuncia na \#globogolpista!.

Essas reações visíveis à empresa e ao produto ocorrem de forma explícita, possibilitada, em particular, pelo suporte Facebook, ao contrário das reações provocadas em anúncios veiculados em suporte impresso, por exemplo. Há, diante desse fato, o indicativo de que essa ação é um fator modificador do gênero.

A postagem do texto publicitário a seguir (Figura 03) foi feita pela empresa Natura em seu mural do Facebook.

\footnotetext{
${ }^{13}$ Como aconteceu com os anúncios da Itaipava: devido às críticas ao apelo machista e de nudez, os anúncios mudaram a cara. A garota propaganda está com roupa comportada e os textos verbais, mais voltados para o produto, como o público deseja.
} 

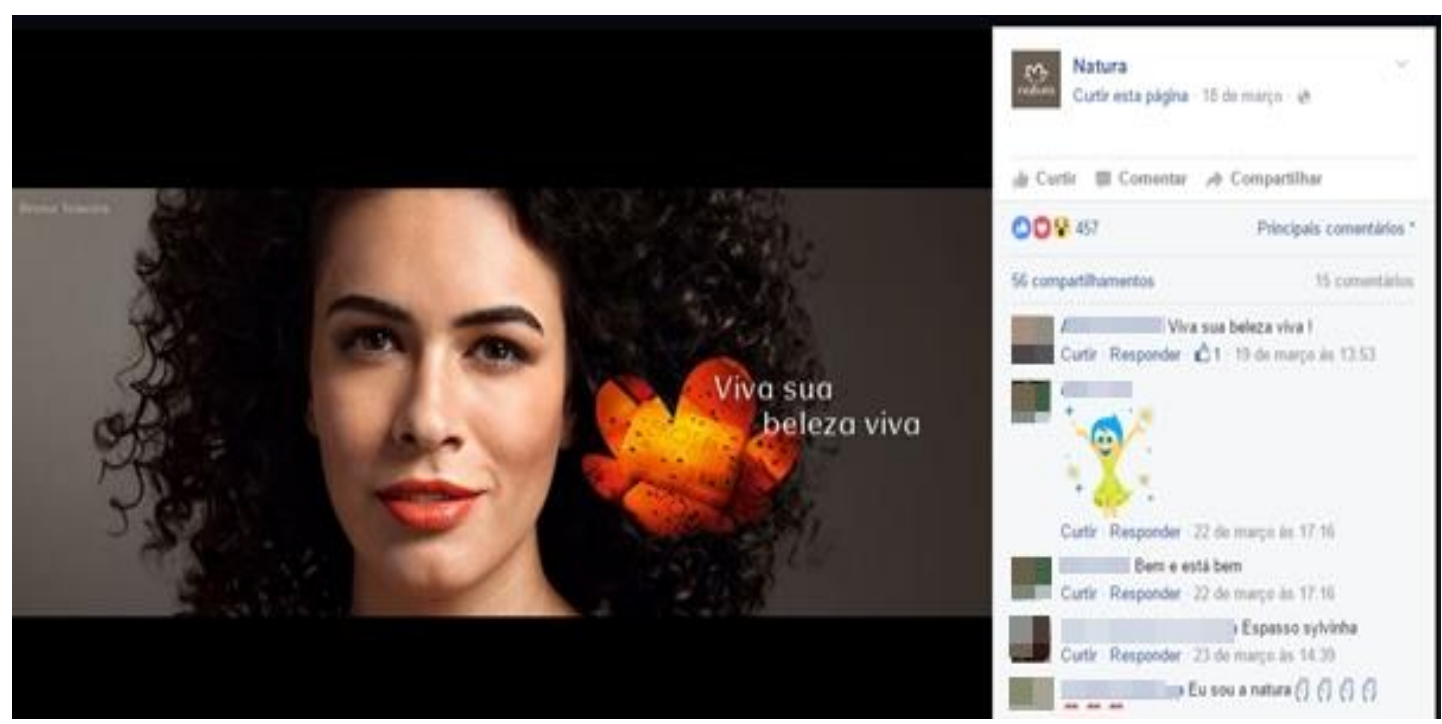

Figura 03 - Texto publicitário da Natura. Fonte: Natura (2016, não paginado).

Utilizando um grande espaço no suporte, observamos uma relação harmoniosa entre a empresa Natura e seus consumidores. Ao contrário do anunciante anterior, nos anúncios analisados dessa marca não ocorreram críticas negativas à empresa, o que não quer dizer que elas não existam e que não sejam oportunas também. No texto publicitário em questão, a empresa Natura mostra a relação entre consumidor e produto consumido. Utilizando os recursos imagético e verbal, a marca busca convencer os usuários que usam esse suporte sobre a qualidade do produto.

$\mathrm{Na}$ imagem de uma mulher com cabelos cacheados, com uma flor nos cabelos, o anúncio destaca, na flor, o produto (sabonete da marca) na cor laranja. A mesma coloração nos lábios da mulher é também uma forma de divulgar outros produtos da empresa, como o batom. A imagem nos autoriza tal constatação, haja vista o uso da mesma cor. O texto verbal Viva sua beleza viva reforça e comprova as intenções do anunciante, bem como a harmonia entre texto verbal e visual. 
Observemos como os consumidores respondem a esse anúncio, com base nos comentários da Figura 03.

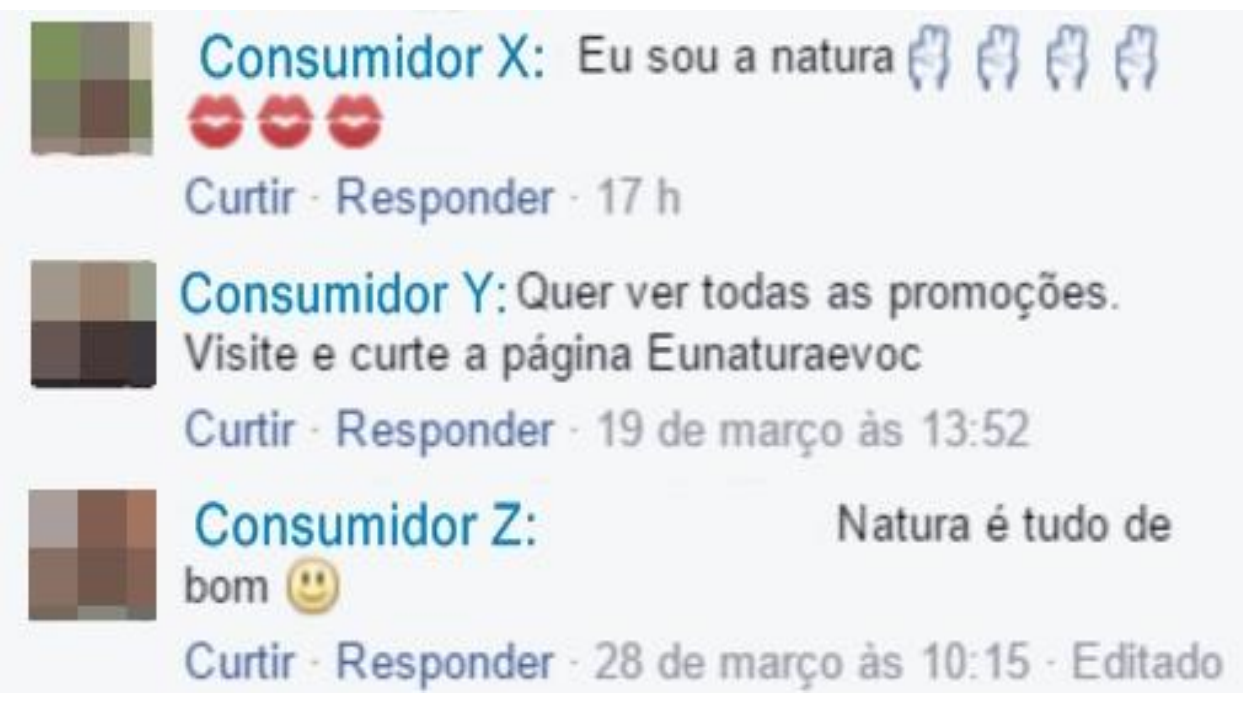

Figura 04 - Comentários sobre o anúncio da Figura 03. Fonte: Natura (2016, não paginado).

Os comentários em relação ao post da Natura são positivos como se pode perceber em: Consumidor X: Eu sou a Natura e em Consumidor Z: Natura é tudo de bom.

Além disso, a marca continua a ser divulgada não mais pela empresa, mas por uma consumidora ou revendedora que comenta: Consumidor Y: Quer ver todas as promoções. Visite e curte a página Eunaturaevoc.

Nesse sentido, a empresa conta não somente com o feedback dos seus consumidores, mas também com a sua ajuda na divulgação da marca e das promoções dos produtos. Como já destacamos, a mensagem Viva sua beleza viva complementa a imagem e completa o sentido pretendido. Esse tipo de anúncio alcança o efeito persuasivo que o hiperlink fornece ao leitor/consumidor que deseja, no mesmo momento, conhecer outros produtos da marca e adquirilos, além do fato de que a empresa pode complementar sua divulgação colocando vídeos da marca ao lado das postagens, proporcionando, assim, mais liberdade ao anúncio. 
Neste anúncio, percebemos mais um elemento importante que particulariza o gênero, favorecido pelo suporte Facebook: a solidariedade dos consumidores ao ajudar a divulgar e promover os produtos anunciados.

\subsection{Contraponto: Havaianas e Natura}

$\mathrm{Na}$ análise dos 10 anúncios publicitários coletados das páginas do Facebook das Havaianas e da Natura, observamos que todos eles apresentaram marca de interação entre enunciador/anunciante e receptor/provável consumidor, bem como maior uso de texto imagético, em relação ao verbal. Oito dos dez anúncios apresentaram marca de participação direta do leitor/provável consumidor na construção do texto do anúncio. O uso de hiperlinks apareceu em nove dos dez anúncios analisados (ver Quadro 1, a seguir, que resume o que afirmamos).

\begin{tabular}{|c|c|c|c|c|}
\hline \multirow[b]{2}{*}{$\begin{array}{c}\text { Textos } \\
\text { Publicitários }\end{array}$} & \multicolumn{4}{|c|}{ Marcas } \\
\hline & $\begin{array}{c}\text { Interação } \\
\text { enunciador/vendedor e } \\
\text { receptor/consumidor. }\end{array}$ & $\begin{array}{c}\text { Participação direta do } \\
\text { leitor/consumidor na } \\
\text { construção do texto } \\
\text { divulgado. }\end{array}$ & $\begin{array}{c}\text { Uso do hiperlink para dar } \\
\text { acesso a vídeos, site e } \\
\text { outras redes sociais da } \\
\text { empresa. }\end{array}$ & $\begin{array}{l}\text { Predominância } \\
\text { do texto } \\
\text { imagético. }\end{array}$ \\
\hline Natura1 & sim & sim & sim & sim \\
\hline Natura2 & sim & $\operatorname{sim}$ & sim & sim \\
\hline Natura3 & $\operatorname{sim}$ & $\operatorname{sim}$ & $\operatorname{sim}$ & $\operatorname{sim}$ \\
\hline Natura4 & sim & sim & sim & sim \\
\hline Natura5 & sim & não & $\operatorname{sim}$ & sim \\
\hline Havaianas 1 & sim & sim & sim & sim \\
\hline Havaianas2 & sim & sim & não & sim \\
\hline Havaianas3 & sim & sim & sim & sim \\
\hline Havaianas4 & sim & não & sim & sim \\
\hline Havaianas5 & sim & sim & sim & sim \\
\hline TOTAL: 10 & $10=100 \%$ & $8=80 \%$ & $9=90 \%$ & $10=100 \%$ \\
\hline
\end{tabular}

Quadro 1 - Marcas textual-discursivas nos textos publicitários da Natura e das Havaianas no Facebook. Fonte: Elaboração dos autores, Fortaleza, 2016.

Essas constatações, defendemos, são fortes indícios que nos levam a afirmar que o Facebook é um suporte de gêneros na web, pois promove adaptações no gênero anúncio publicitário analisado e, provavelmente, nos gêneros em geral. 


\section{Considerações finais}

A relação entre gênero e suporte é inevitável, afinal não existem gêneros (especialmente gêneros escritos) que não sejam fixados, postados em um suporte.

Essa relação não é independente, pois um determinado suporte pode receber diversos gêneros, como é o caso do Facebook, embora haja suportes que são necessariamente dependentes de certos gêneros. O outdoor é um suporte convencional pensado prioritariamente para veicular propagandas e anúncios publicitários. Hoje, contudo, este suporte abriga uma variedade de gêneros, além dos anúncios e propagandas, como: declarações pessoais, mensagens de aniversário, de divulgação de programas de curso, entre outros.

Suporte e gênero, em essência, são entidades inter-relacionadas, porém gênero e suporte preservam sua independência e sua função social.

O Facebook pode ser considerado um suporte que, entre outras funções, modifica o gênero publicitário, afirmação que se fundamenta nas leituras e análises realizadas neste estudo. O Facebook, com sua estrutura em páginas e com variados recursos, permite a realização dos objetivos dos gêneros publicitários, principalmente no que se refere à interação entre emissor/anunciante e receptor/consumidor. Além disso, o Facebook reconfigura a ideia de consumidor anônimo, pois o consumidor não é mais considerado anônimo nesse suporte.

O Facebook, portanto, sendo (entendido como) suporte, apresenta arranjos de modo a permitir que haja relação com o gênero, pois favorece o uso de linguagem capaz de promover modificações nos gêneros discursivos, característica própria de um suporte.

\section{Referências}

ARAUJO, Gabriel Campelo et al. Publicidade nas redes sociais. In: CONGRESSO BRASILEIRO DE CIÊNCIAS DA COMUNICAÇÃO, 32., 2009, Curitiba. Anais... Curitiba: Intercom/Universidade Positivo, 2009. p. 1-15.

BAKHTIN, Mikhail. Os gêneros do discurso. In: Estética da criação verbal. 4. ed. Tradução de Paulo Bezerra. São Paulo: Martins Fontes, 2003. p. 261-306.

BAWARSHI, Anis S; REIFF, Mary Jo. Gênero: história, teoria, pesquisa, ensino. Tradução de Benedito Gomes Bezerra. São Paulo: Parábola, 2013. 
BERNARDO, Julio Cesar Oliveira. Hipertexto, diversidade e gênero textual no Facebook. In: SIMPÓSIO INTERNACIONAL DE ENSINO DE LÍNGUA PORTUGUESA, 4., 2014, Uberlândia. Anais... Uberlândia: EDUFU, 2014. p. 1-9.

BHATIA, Vijay K. Analysis genre: language use in professional settings. London/New York: Longman, 1993.

BHATIA, Vijay K. Integrating products, processes, purposes and participants in profissional writing. In: CANDLIN, Christopher N.; HYLAND, Ken. (Ed.). Writing: texts, processes and practices. London/New York: Longman, 1999. p. 19-39.

BHATIA, Vijay K. Worlds of written discourse: a genre-based view. London: Continuum, 2004.

BIASI-RODRIGUES, Bernardete; HEMAIS, Barbara; ARAÚJO, Júlio César. Análise de gêneros na abordagem de swales: princípios teóricos e metodológicos. In: BIASI-RODRIGUES, Bernardete; ARAÚJO, Júlio César; SOUSA, Socorro Cláudia Tavares de (Org.). Gêneros textuais e comunidades discursivas: um diálogo com John Swales. Belo Horizonte: Autêntica, 2009. p. 17-32.

CARVALHO, Nelly de. Linguagem da publicidade. Recife: Ed. Universitária da UFPE, 2014.

GONZALES, L. Linguagem publicitária: análise e produção. São Paulo: Editora Arte e Ciência, 2003.

HAVAIANAS. Apenas o essencial em uma mala viagem. Facebook: @ HavaianasBrasil. Disponível: 〈https://www.facebook.com/HavaianasBrasil/timeline>. Acesso em: 03 abr. 2016.

LIMA-NETO, Vicente de. Um estudo da emergência de gêneros no Facebook. 2014. 312 f. Tese (Doutorado em Linguística) - Programa de Pós-graduação em Linguística, Universidade Federal do Ceará, Fortaleza, 2014.

LOPES, Ana Keyla Carmo. Uma colônia de gêneros anúncios. 2008. 181 f. Dissertação (Mestrado em Linguística) - Programa de Pós-graduação em Linguística, Universidade Federal do Ceará, Fortaleza, 2008.

MARCUSCHI, Luiz Antônio. Produção textual, análise de gêneros e compreensão. 2. ed. São Paulo: Parábola Editorial, 2008.

MARCUSCHI, Luís Antônio; XAVIER, Antônio Carlos (Org.). Hipertexto e gêneros digitais: novas formas de construção de sentido. 2. ed. Rio de Janeiro: Lucerna, 2005.

MARTINS, Jorge S. Redação publicitária: teoria e prática. São Paulo: Atlas. 1997.

MILLER, Carolyn R. Genre as social action. In.: FREDMAN, Aviva; MEDWAY, Peter (Ed.). Genre and the new rhetoric. London/Bristol: Taylor e Francis, 2012. p. 23-66. 
MOREIRA, Maria Ednilza Oliveira. O processo de revisão da escrita: o que o docente privilegia no trabalho com o texto. 2009. 286 f. Tese (Doutorado em Linguística) - Programa de Pósgraduação em Linguística, Universidade Federal do Ceará, Fortaleza, 2009.

NATURA. Viva sua beleza viva. Facebook: @natura.br. Disponível: <https://www.facebook.com/natura.br/>. Acesso em: 03 abr. 2016.

SOUSA, Maria Margarete Fernandes de. A organização textual-discursiva dos anúncios de turismo no Ceará. 2005. 212 f. Tese (Doutorado em Linguística) - Programa de Pós-graduação em Linguística, Universidade Federal do Pernambuco, Recife, 2005.

SWALES, John M. Genre analysis: English in academic and research settings. New York: Cambridge University Press, 1990.

SWALES, John M. Sobre modelos de análise do discurso. In: BIASI-RODRIGUES, Bernardete; ARAÚJO, Júlio César; SOUSA, Socorro Cláudia Tavares de (Org.). Gêneros textuais e comunidades discursivas: um diálogo com John Swales. Belo Horizonte: Autêntica, 2009. p. 33 46.

TÁVORA, Antônio Duarte Fernandes. Construção de um conceito de suporte: a matéria, a forma e a função interativa na atualização de gêneros textuais. 2008. 183 f. Tese (Doutorado em Linguística) - Programa de Pós-graduação em Linguística, Universidade Federal do Ceará, Fortaleza, 2008.

Recebido em 27 de maio de 2019. Aceito em 27 de novembro de 2019. 